\title{
Severe Carbamazepine-Induced Cutaneous Reaction in the Treatment of Post-herpetic Neuralgia. Case Report
}

\author{
João Batista Santos Garcia, TSA 1, Letácio Santos Garcia Ferro ², Anamada Barros Carvalho ${ }^{3}$, \\ Rosyane Moura da Rocha ${ }^{2}$, Livia Maria Lima de Souza ${ }^{2}$
}

\begin{abstract}
Summary: Garcia JBS, Ferro LSG, Carvalho AB, Rocha RM, Souza LML - Severe Carbamazepine-Induced Cutaneous Reaction in the Treatment of Post-herpetic Neuralgia. Case Report.

Background and objectives: Post-herpetic neuralgia (PHN) is the main complication of herpes zoster. Carbamazepine (CBZ), a well-tolerated anticonvulsant, but frequently associated with severe cutaneous reactions, such as the Stevens-Johnson syndrome (SJS) and toxic epidermal necrolysis (TEN) is used in the treatment of this complication. The objective of this article was to report a case of SJS/TEN secondary to CBZ in a patient with $\mathrm{PHN}$.
\end{abstract}

Case report: This is a female patient with continuous severe, burning, chock-like pain in the thoracic region and dorsum associated with reduced strength in the ipsilateral upper limb and diaphoresis. She had crusty and erythematous lesions in the dorsal region of the thorax with allodynia and dysesthesia in the affected dermatome. She was treated with CBZ $300 \mathrm{mg}^{\text {.day }}{ }^{-1}$, amitriptyline (AMT) $12.5 \mathrm{mg}$ at bedtime, and infiltration with local anesthetic in the affected region. After 15 days, she developed malaise, fever, muscle pain, and arthralgia with a mild non-specific cutaneous rash. Carbamazepine was discontinued immediately. One week later, she was hospitalized with urticaria, generalized exanthema, erythematous cutaneous eruptions, bullae, and purpuric maculae all over her body. The impression was of carbamazepine-induced SJS/TEN. She evolved with progressive worsening of her symptoms, with increase in the number and size of cutaneous lesions, besides generalized erythematous macular rash, areas of necrosis, and erosions with symmetrical loosening of the epidermis in face, neck, thorax, dorsum, and limbs, affecting more that $50 \%$ of her body surface, besides involvement of buccal, conjunctival, and genital mucosa with vesicular erosions. She had progressive functional worsening, evolving to septic shock and multiple organ failure followed by death.

Conclusions: Stevens-Johnson syndrome and toxic epidermal necrolysis are severe cutaneous reaction with potential for elevated morbidity and mortality that requires immediate intervention and adequate management. In addition, we would like to alert that the use of Carbamazepine should be supervised, especially in the elderly.

Keywords: COMPLICATIONS: toxic epidermal necrolysis, Stevens-Johnson syndrome; DISEASES, Viral: herpes zoster; DRUGS, Anticonvulsant: carbamazepine.

[Rev Bras Anestesiol 2010;60(4): 429-437] OElsevier Editora Ltda.

\section{INTRODUCTION}

Post-herpetic neuralgia (PHN) is the main complication of herpes zoster $(\mathrm{HZ})$, resulting from the reactivation of the varicella-zoster virus. Among the drugs used in the treatment of this painful syndrome is carbamazepine (CBZ), a well-tolerated anticonvulsant, but that is frequently associated with severe cutaneous reactions, such as the Stevens-Johnson syndrome (SJS) and toxic epidermal necrolysis (TEN). They

Received from the Outpatient Pain Clinic of Instituto Maranhense de Oncologia, São Luís, MA, where the activities of the Liga Acadêmica de Dor of Universidade Federal do Maranhão (UFMA) are developed.

1. Anesthesiology Professor of UFMA; Responsible for the Department of Pain of HU/UFMA and of Instituto Maranhense de Oncologia

2. Physician; Collaborator of the Liga Acadêmica de Dor of UFMA

3. Physiatrist; Collaborator of the Liga Academica de Dor of UFMA

Submitted on January 14, 2010.

Approved on March 18, 2010

correspondence to:

João Batista Santos Garcia

Av. São Marcos, L4, Quadra C, apt 502

65077-310 - São Luís, MA

E-mail:jbgarcia@uol.com.br are immunomediated reactions to the drug and can be characterized as a hypersensitivity syndrome due to the preexistence of pharmacogenetic and immunologic abnormalities to the drug. Clinically they present as erythema, necrosis, and extensive sloughing of the epidermis, mucous involvement, and systemic symptoms. Fast diagnosis is essential since withdrawal of the drug is the most important action to minimize the resulting morbidity 1,2 . The objective of this article was to report a case of SJS/TEN secondary to CBZ in a patient with PHN.

\section{CASE REPORT}

This is a 61 years old female referred in August 2007 to the Outpatient Pain Clinic with a 15-day history of continuous pain in the thoracic region and dorsum irradiating to the left $5^{\text {th }}$ intercostal space, severe (numeric scale at 10 ), burning, shock-like associated with changes in the strength of the ipsilateral upper limb, and diaphoresis that worsened with cold and improved with butylscopolamine. On physical exam she presented crusty, erythematous lesion in the dorsal region of 
the thorax suggestive of herpes zoster infection with severe allodynia and dysesthesia in the affected dermatome. Car-

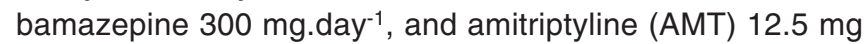
at bedtime were instituted and the affected area was infiltrated with local anesthetic. After 15 days she returned complaining of malaise, fever, muscle pain, and arthralgia with a mild and non-specific rash. It was decided to discontinue the carbamazepine immediately. One week later, she was hospitalized with urticaria and generalized exanthema, erythematous cutaneous eruptions, bullous and macular purpura all over her body. The clinical impression was carbamazepineinduced SJS/TEN (Figure 1). Amitriptyline was maintained and codeine and dypirone were started as adjuvant to pain control. The patient evolved with fast and progressive worsening, with increase in the number and size of the cutaneous lesions. A generalized erythematous rash was observed, as well as areas of necrosis and erosions with symmetrical sloughing of the epidermis in the face, neck, thorax, dorsum, and upper and lower limbs affecting more than $50 \%$ of her body surface area; she also had involvement of buccal, conjunctival, and genital mucosa with painful erosions and vesicular lesions. The patient was transferred to the Intensive Care Unit (ICU) with progressive functional worsening of respiratory and cardiovascular systems and after two weeks she developed septic shock and multiple organ failure, following by death.

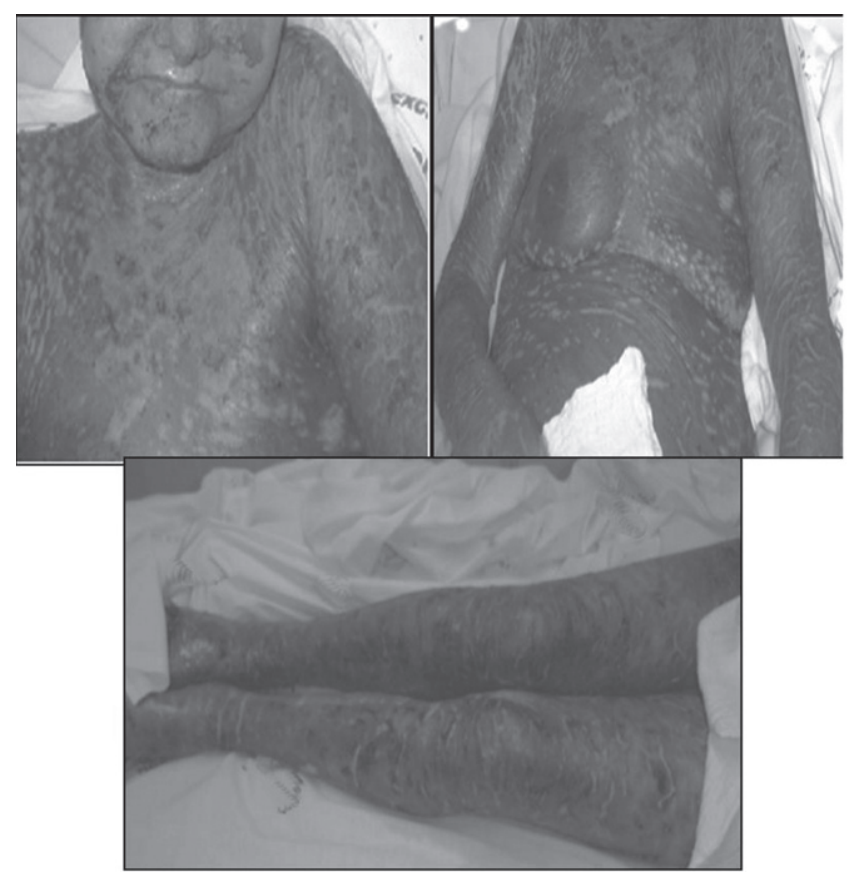

Figure 1 - Face, Thorax, and Upper Limbs Showing Cutaneous Eruptions, Mucous Erosions, and Epidermal Sloughing.

\section{DISCUSSION}

The varicella-zoster virus (VZV) remains hidden after penetrating in the nervous system especially in cranial nerves and dorsal root ganglia ${ }^{3-5}$. It is frequently reactivated leading to $\mathrm{HZ}$ characterized by the presence of erythematous plaques covered with grouped vesicles with unilateral distribution circumscribed to one dermatome, and associated with paresthesia or pain ${ }^{6}$. Among the risk factors, age is the most common being reported mainly in patients over 50-60 years of age ${ }^{3,6-8}$.

Post-herpetic neuritis, the main complication of $\mathrm{HZ}$, has an incidence that ranges from 10 to $20 \%$, and it is defined as pain that remains after the disappearance of the vesicles of the acute episode after a period of at least 6 weeks ${ }^{4,6,9}$. Treatment of $\mathrm{PHN}$ should be done with drugs to control and relieve the pain. On a recent review ${ }^{10,11}$ the efficacy of existing treatments was classified in categories as first line analgesics in which tricyclic antidepressants, anticonvulsants, and lidocaine patches (proven efficacy) were included; and second line analgesics, in which opioids were included. Neural blocks could also be considered potential treatment ${ }^{11,12}$. Although less effective and with more side effects ${ }^{11,13,14}$ carbamazepine still is an anticonvulsant commonly used in the treatment of $\mathrm{PHN}$ 9,15,16.

Cutaneous reactions to drugs are common, affecting $2 \%$ to $3 \%$ of hospitalized patients. Fortunately the majority of the reactions are not severe, and very few are fatal. Some clinical and laboratorial signs can be found in the suspected diagnosis of severe cutaneous reactions, and can be considered an alert for our initial recognition (Chart 1) ${ }^{17}$.

When our patient returned to the clinic after 15 days she presented fever, malaise, and non-specific cutaneous rash. Despite discontinuing CBZ, one week later her state was more severe. We were facing a diagnostic challenge since our hypothesis of

Chart 1 - Clinical and Laboratorial Picture that Alert for Drug-Induced Reactions

\begin{tabular}{ll}
\hline Clinical Picture & Clinical picture \\
\hline Cutaneous & Eosinophilia $\left(>1000 \mathrm{cel} / \mathrm{mm}^{3}\right)$ \\
Confluent erythema & Lymphocystosis with atypical \\
& lymphocytes
\end{tabular}

Pain

Epidermal necrosis

Facial edema

Palpable purpura

Pustules or epidermal sloughing

Positive Nikolsky sign

Mucosal erosions

Urticaria

Tongue edema

General

High fever (> 40ㄷ)

Adenomegaly

Arthralgia or arthritis

Hypotension

Source: Adapted from Roujeau and Stern (1994) 
SJS/TEN represented an intense idiosyncratic reaction, not too frequent, but caused by drugs and with a significant mortality rate ${ }^{18,19}$. Initially, it was considered that SJS was similar to major erythema multiforme (EM) until less than two decades ago some authors proposed that they are two distinct disorders with similar mucous erosions, but with clinical differences and in the pattern of the cutaneous lesions ${ }^{7,20-24}$ (Chart 2).

It was proposed in additional studies that SJS and TEN are the same disease, but with distinct severity. A recent classification proposed that sloughing of the epidermis or positive Nikolsky sign in SJS is limited to $10 \%$ of the body surface area (BSA); in the transition of SJS/TEN it is limited to between 10 and $30 \%$ of BSA; and in TEN the sloughing of the necrotic epidermis is greater than $30 \%$ of BSA $18,21-23,25-28$.

Several estimates of the incidence of SJS, superposition of SJS/TEN, and TEN are referred due to the spectrum and clinical variability. However, as a rule the estimate ranges from 1 to 6 and 0.4 to 1.3 cases per million individuals a year for SJS and TEN respectively ${ }^{19,21}$. Both adults and children are involved, but it is more common in females. The age of patients with SJS ranges from 25 to 47 years while TEN affects older patients from 46 to 63 years ${ }^{18}$.

Chart 2 - Characteristics and Comparison between Erythema Multiforme and Stevens-Johnson Syndrome/Toxic epidermal Necrolysis

Erythema Multiforme

(n)

Infection: herpes simples virus, Mycoplasma

Lesions: erythematous papules

Involvement of three regions

Without fever and other

constitutional symptoms

Up to $10 \%$ of the body surface area

Moderate course, recovery

in 1-4 weeks

Recurrence is common, related to herpes simples

Stevens-Johnson Syndrome/

Toxic Epidermal Necrolysis

Drug-induced

Lesions: dark macula

Atypical involvement

Fever, headache, myalgia

Extensive epidermal necrolysis

Elevated mortality in severe cases

Recurrence is uncommon, related to the presence of the drug

Source: Adapted from Fritsch and Maldonado (2003).

Chart 3 - Drugs and Risk of the Stevens-Johnson Syndrome and Toxic Epidermal Necrolysis

\begin{tabular}{ll}
\hline High Risk & Low Risk \\
NSAIDs (Oxicam) & Aminopenicillins \\
Allopurinol & Cephalosporins \\
Carbamazepine & Fluoroquinolones \\
Phenytoin & Macrolides \\
Phenobarbital & \\
Lamotrigine & \\
Sulfadiazine & \\
Sulfamethoxazole & \\
Sulfapyridine & \\
\hline
\end{tabular}

Source: Adapted from Fritsch and Maldonado (2003).
Although the etiology of SJS/TEN is multiple it is commonly triggered by viral infections (herpes simplex virus is the infectious agent more commonly involved) ${ }^{29}$ and neoplasias (carcinomas and lymphomas). However, the most common cause is the use of drugs ranging from $80 \%$ to $95 \%$ for TEN, and $30 \%$ to $50 \%$ for SJS. Among the drugs implicated more often are allopurinol, antibiotics (sulfonamides, pencillins, cephalosporins), anticonvulsants (carbamazepine, lamotrigine, phenobarbital), and non-steroid anti-inflammatories (NSAIDS) $17-19,21,23,30,31$

In the decade of 1990 a quantitative case-controlled study on the relative risk of SJS/TEN with those drugs which confirmed a substantial increase in their risk was published ${ }^{32}$. In 2007, a multinational study involving Europe and Israel (EuroSCAR) concluded that allopurinol was the most common cause of SJS/TEN in those areas 18,27,33. More recently, in a sevenyear study Devi $\mathrm{K}$ et al. concluded that anticonvulsants were the cause implicated more often in SJS/TEN especially in the first eight weeks of treatment ${ }^{34}$, and the main drug responsible (more than $80 \%$ ) was carbamazepine ${ }^{35}(12-20 \text { days })^{36}$. In a retrospective study conducted in 2008 SJS/TEN was more common with the use of anticonvulsants, antibiotics, and ANSAIDs ${ }^{37}$. Prescribing those drugs requires deep assessment of the expected benefits ${ }^{36}$, with recommendation of gradual titration at the beginning of treatment especially with anticonvulsants ${ }^{18,38}$ (Chart 3 ).

Typically, the initial presentation is marked by a prodrome of fever, and symptoms resembling infection with influenza for 1 to 3 days before the development of cutaneous lesions. Pain and burning of the eyes develop progressively, announcing the involvement of mucous membranes and rapid progression of systemic signs and symptoms 18,19,27. The skin lesions are symmetrical and begin with a confluent erythema, papules, vesicles, bullae, or urticarial plaques with the center of the lesions with a vesicular, purpuric, or necrotic aspect affecting face, upper part of the trunk, and proximal extremities that progresses rapidly to involve the remaining areas. The pathognomonic lesion has the appearance of a bull's eye, and it can evolve, coalesce, or increase in size and number. Thus, Nikolsky sign (sloughing of the skin with mild friction) can be present and make it susceptible to secondary infection. Mucous involvement is seen in $90 \%$ of the cases, preceding or succeeding the cutaneous involvement 17-19,27.

The evolution gives rise to erosions in the mucous membranes with formation of pseudomembranous formations on the eyes, mouth, genitals, and oropharynx. Exposure to the drug precedes the onset of symptoms by one to three weeks $17,21,27$. The time of evolution of SJS/TEN from the beginning of the prodrome until the hospitalization in the absence of significant complications ranges from one to four weeks ${ }^{18}$. Finally, visceral involvement including pulmonary, renal, and gastrointestinal tract is also possible. The severity is proportional to the extension of skin necrosis, which gives patients the aspect of large burns leading to loss of proteins and electrolytes, bacterial colonization, infection, and sepsis 17,26,39.

Diagnosis is clinical; however, skin biopsy for histological routine and immunofluorescence study should be done in all 
cases of epidermal necrolysis to exclude differential diagnosis and of definitive confirmation 17-19,27. Regarding the laboratorial diagnosis the $\mathrm{CBC}$ can reveal important anemia and lymphopenia, eosinophilia, and neutropenia, and the latter is related to a worse prognosis. Moderate elevation of hepatic enzymes and amylase are frequent as well as altered renal function ${ }^{17,19,21}$. Blood, urine, and wound cultures are indicated when subjacent infection is suspected. In TEN cutaneous biopsy shows the dermis with a minimal infiltrate of inflammatory cells predominating T lymphocytes CD4+, necrosis of the epidermis in which predominated T lymphocytes CD8+, and abundant deposits of tumor necrosis factor-alpha (TNF- $\alpha$ ).

In patients with SJS the dermal-epidermal junction has vacuolar alterations and subepidermal blisters. The dermal infiltrate is superficial and for the most part perivascular, and on electron microscopy the conjunctiva reveals squamous epithelial metaplasia, vascular disruption, and reduplication ${ }^{21}$. In the present case, the hypothesis of SJS/TEN was made by the percentage of epidermal sloughing, but a biopsy to confirm the diagnosis was not possible.

In 2007, on an information released by the FDA (Food and Drug Administration) drug-induced fatal cutaneous reactions (SJS/TEN) are more common in patients with a particular allele of the human leukocyte antigen (HLA), HLA-B*1502. This allele is seen almost exclusively in patients from some areas of Asia. Genetic testing in patients with ancestors from areas in which HLA-B*1502 should be evaluated for this allele before the onset of treatment with carbamazepine. If the test is positive, this drug should not be initiated unless the expectation of benefits is clearly superior to the increased risk of cutaneous reactions. This is true for patients of any ethnicity and genotype including patients positive for HLA-B*1502 ${ }^{40-43}$.

The main therapeutic action in SJS/TEN is the early recognition of the reaction and withdrawal of the drug, since the delay can be seriously deleterious for the patient. The management of the patient involves specific care and in most cases transference to the intensive care unit $28,39,44$.

Mortality in SJS/TEN is approximately $5 \%$, but it is increased with an increase in the age of the patient and in the area of epidermal sloughing. As a rule, skin lesions do not leave scars, but mucous lesions could be a late complication, and they can cause bleeding and narrowing of affected areas ${ }^{45}$.

Stevens-Johnson syndrome and TEN represent a serious cutaneous reaction with the potential for elevated morbidity and mortality, which require fast and adequate management. One should always remember that the use of carbamazepine should always be under supervision, especially in the elderly. 


\section{REFERÊNCIAS / REFERENCES}

01. Klassen BD, Sadler RM. Induction of hypersensitivity to a previously tolerated antiepileptic drug by a second antiepileptic drug. Epilepsia, 2001:42:433-435.

02. Durán-Ferreras E. Mir-Mercader J, Morales-Martínez MD et al. Síndrome de hipersensibilidad por antiepilépticos con repercusión cutánea y renal grave por carbamazepina. Rev Neurol, 2004;38:1136-1138.

03. Johnson RW, Wasner G, Saddier P et al. Herpes zoster and postherpetic neuralgia: optimizing management in the elderly patient. Drugs Aging, 2008;25:991-1006.

04. Gilden DH, Kleinschmidt-DeMasters BK, LaGuardia JJ et al. Neurologic complications of the reactivation of varicella-zoster virus. N Engl J Med, 2000;342:635-645.

05. Kennedy PG, Grinfeld E, Bell JE. Varicella-zoster virus gene expression in latently infected and explanted human ganglia. $\mathrm{J}$ Virol, 2000;74:11893-11898.

06. Stankus SJ, Dlugopolski M, Packer D. Management of herpes zoster (shingles) and postherpetic neuralgia. Am Fam Physician, 2000;61:2437-2444.

07. McCrary ML, Severson J, Tyring SK. Varicella zoster virus. J Am Acad Dermatol, 1999;41:1-14.

08. Straus SE, Ostrove JM, Inchauspe G et al. NIH conference. Varicellazoster virus infections. Biology, natural history, treatment, and prevention. Ann Intern Med, 1988;108:221-237.

09. Dubinsky RM, Kabbani H, El-Chami Z et al. Practice parameter: treatment of postherpetic neuralgia: an evidence-based report of the Quality Standards Subcommittee of the American Academy of Neurology. Neurology, 2004;63:959-965.

10. Wu CL, Raja SN. An update on the treatment of postherpetic neuralgia. J Pain, 2008; 9(1suppl 1):s19-s30.

11. Attal N, Cruccu G, Haanpää M et al. EFNS guidelines on pharmacological treatment of neuropathic pain. Eur J Neurol, 2006;13:1153-1169.

12. Schmader KE, Dworkin RH. Natural history and treatment of herpes zoster. J Pain, 2008; 9(suppl 1):s3-s9.

13. Johnson RW, Wasner G, Saddier P et al. Herpes zoster and postherpetic neuralgia: optimizing management in the elderly patient. Drugs Aging, 2008;25:991-1006.

14. Argoff CE, Katz N, Backonja M. Treatment of postherpetic neuralgia: a review of therapeutic options. J Pain Symptom Manage, 2004;28:396411.

15. Douglas MW, Johnson RW, Cunningham AL. Tolerability of treatments for postherpetic neuralgia. Drug Saf, 2004;27:1217-1233.

16. Rowbotham M, Harden N, Stacey B et al. Gabapentin for the treatment of postherpetic neuralgia: a randomized controlled trial. JAMA, 1998;280:1837-1842.

17. Roujeau JC, Stern RS. Severe adverse cutaneous reaction to drugs. N Engl J Med, 1994;331:1272-1285.

18. Nirken MH, High WA. Stevens-Johnson syndrome and toxic epidermal necrolysis: Clinical manifestations, pathogenesis, and diagnosis. Disponível em: http://www.uptodate.com/patients/content/search. do?search=Stevens-Johnson.

19. Fritsch PO, Ruiz-Maldonado R. Erythema Multiforme, Stevens-Johnson Syndrome and Toxic Epidermal Necrolysis. em: Freedberg IM, Eisen AZ, Wolff $\mathrm{K}$ et al. Fitzpatrick's Dermatology in General Medicine, $6^{\text {th }}$ Ed, New York: McGraw-Hill, 2003;543-559.

20. Parrillo SJ. Stevens-Johnson syndrome and toxic epidermal necrolysis. Curr Allergy Asthma Rep, 2007;7):243-247.

21. Letko E, Papaliodis DN, Papaliodis GN et al. Stevens-Johnson syndrome and toxic epidermal necrolysis: a review of the literature. Ann Allergy Asthma Immunol, 2005;94:419-436. 
22. Bastuji-Garin S, Rzany B, Stern RS et al. Clinical classification of cases of toxic epidermal necrolysis, Stevens-Johnson syndrome, and erythema multiforme. Arch Dermatol, 1993;129:92-96.

23. Roujeau JC. Stevens-Johnson syndrome and toxic epidermal necrolysis are severity variants of the same disease which differs from erythema multiforme. J Dermatol, 1997;24:726-729.

24. Auquier-Dunant $A$, Mockenhaupt $M, N a l d i ~ L$ et al. Correlations between clinical patterns and causes of erythema multiforme majus, Stevens-Johnson syndrome, and toxic epidermal necrolysis: results of an international prospective study. Arch Dermatol, 2002;138:10191024.

25. Assier H, Bastuji-Garin S, Revuz $\mathrm{J}$ et al. Erythema multiforme with mucous membrane involvement and Stevens-Johnson syndrome are clinically different disorders with distinct causes. Arch Dermatol, 1995;131:539-543.

26. Criado PR, Criado RFJ, Vasconcellos $C$ et al. Reações cutâneas graves adversas a drogas - aspectos relevantes ao diagnóstico e ao tratamento. Parte I - Anafilaxia e reações anafilactoides, eritrodermias e o espectro clínico da síndrome de Stevens-Johnson \& necrólise epidérmica tóxica (Doença de Lyell). An Bras Dermatol, 2004;79(4):471-488.

27. Klein PA. Stevens-Johnson Syndrome and Toxic Epidermal Necrolysis. Disponível em: http://emedicine.medscape.com/article/1124127overview.

28. French LE. Toxic epidermal necrolysis and Stevens Johnson syndrome: our current understanding. Allergol Intern, 2006;55:9-16.

29. Gomez-Criado MS, Ayani I, Leon-Colombo T et al. Sindrome de Stevens-Johnson, necrolisis epidermica toxica y fenitoina. Factores asociados a un aumento del riesgo.. Rev Neurol, 2004;38:1056-1060.

30. Mockenhaupt M, Schöpf E. Epidemiology of drug-induced severe skin reactions. Sem Cutan Med Surg, 1996;15:236-243.

31. Lin MS, Dai -S, Pwu RF et al. Risk estimates for drugs suspected of being associated with Stevens-Johnson syndrome and toxic epidermal necrolysis: a case-control study. Intern Med J, 2005;35:188-190.

32. Roujeau JC, Kelly JP, Naldi $L$ et al. Medication use and the risk of Stevens-Johnson syndrome or toxic epidermal necrolysis. N Engl $\mathrm{J}$ Med, 1995; 333:1600-1607.

33. Halevy S, Ghislain P-D, Mockenhaupt M et al. Allopurinol is the most common cause of Stevens-Johnson syndrome and toxic epidermal necrolysis in Europe and Israel. J Am Acad Dermatol, 2008;58:25-32.

34. Rzany B, Correia O, Kelly JP et al. Risk of Stevens-Johnson syndrome and toxic epidermal necrolysis during first weeks of antiepileptic therapy: a case-control study. Lancet, 1999;353:2190-2194.

35. Devi K, George S, Criton S et al. Carbamazepine - the commonest cause of toxic epidermal necrolysis and Stevens-Johnson syndrome: a study of 7 years. Indian J Dermatol Venereol Leprol, 2005;71:325-328.

36. Mockenhaupt M, Viboud C, Dunant A et al. Stevens-Johnson syndrome and toxic epidermal necrolysis: assessment of medication risks with emphasis on recently marketed drugs. The EuroSCAR-study. J Invest Dermatol, 2008;128:35-44.

37. Sharma VK, Sethuraman G, Minz A. Stevens Johnson syndrome, toxic epidermal necrolysis and SJS-TEN overlap: a retrospective study of causative drugs and clinical outcome. Indian J Dermatol Venereol Leprol, 2008;74:238-240.

38. Mockenhaupt M, Messenheimer J, Tennis P et al. Risk of StevensJohnson syndrome and toxic epidermal necrolysis in new users of antiepileptics. Neurology, 2005;64:1134-1138.

39. Revuz JE, Roujeau JC. Advances in toxic epidermal necrolysis. Semin Cutan Med Surg, 1996;15:258-266.

40. Lonjou $\mathrm{C}$, Thomas $\mathrm{L}$, Borot $\mathrm{N}$ et al. A marker for Stevens-Johnson syndrome: ethnicity matters. Pharmacogenomics J, 2006;6:265-268.
41. Lonjou C, Borot N, Sekula P et al. A European study of HLA-B in Stevens-Johnson syndrome and toxic epidermal necrolysis related to five high-risk drugs. Pharmacogenet Genomics, 2008;18:99-107.

42. U.S. Food and Drug Administration. FDA Information for Healthcare Professionals. December 12, 2007. Disponível em: <http://www.fda. gov/cder/drug/infopage/carbamazepine/default.htm $>$

43. Pirmohamed M, Arbuckle JB, Bowman CEet al. Investigation into the multidimensional genetic basis of drug-induced Stevens-Johnson syndrome and toxic epidermal necrolysis. Pharmacogenomics, 2007;8:1661-1691.

44. Garcia-Doval I, LeCleach L, Bocquet $\mathrm{H}$ et al. Toxic epidermal necrolysis and Stevens-Johnson syndrome: does early withdrawal of causative drugs decrease the risk of death? Arch Dermatol, 2000;136:323327.

45. Ghislain PD, Roujeau JC. Treatment of severe drug reactions: Stevens-Johnson syndrome, toxic epidermal necrolysis and hypersensitivity syndrome. Dermatol Online J, 2002;8:1087-1108.

Resumen: Garcia JBS, Ferro LSG, Carvalho AB, Rocha RM, Souza LML - Reacción Cutánea Grave Inducida por la Carbamazepina en el Tratamiento de la Neuralgia Postherpética. Relato de Caso.

Justificativa y objetivos: El herpes zoster tiene como principal complicación la neuralgia postherpética (NPH). Para su tratamiento se usa la carbamazepina (CBZ), un anticonvulsivo bien tolerado, pero que sin embargo está a menudo asociado a reacciones cutáneas graves, como por ejemplo, el síndrome de Stevens-Johnson (SSJ) y la necrólisis epidérmica tóxica (NET). El objetivo de este trabajo es relatar un caso de SSJ/NET secundario al uso de CBZ en paciente con $\mathrm{NPH}$.

Relato del caso: Paciente del sexo femenino, con dolor continuo e intenso en la región torácica y dorso, ardor, punzada, descarga eléctrica, alteración de fuerza del miembro superior ipsilateral y sudoración. Presentaba lesiones de postillas y eritemas en la región dorsal del tórax, con alodinia y disestesias en el dermatoma acometido. Se inició CBZ

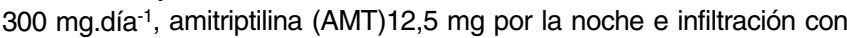
anestésico local en la región afectada. Después de 15 días, el paciente decía sentir un fuerte malestar, fiebre, dolores musculares y artralgias con rash cutáneo ligero e inespecífico. Se le retiró la carbamazepina inmediatamente. Una semana después fue ingresado con urticaria y exantema generalizados, erupciones cutáneas eritematosas, burbujas y marcas purpúricas por todo el cuerpo. La impresión era de SSJ/NET inducida por carbamazepina. Hubo un progresivo empeoramiento del cuadro, con aumento del número y del tamaño de las lesiones cutáneas, además de rash eritematoso macular generalizado, áreas de necrosis y erosiones simétricas de la epidermis en la cara, cuello, tórax, dorso y miembros, llegando a más del $50 \%$ del área de superficie, además de la involucración de la mucosa bucal, conjuntival y genital con erosiones vesiculares. Presentó un empeoramiento funcional progresivo, evolucionando con choque séptico y fracaso multiorgánico, lo que produjo finalmente su deceso.

Conclusiones: La SSJ/NET es una reacción cutánea grave con potencial para la morbilidade y mortalidad elevadas y que exige una intervención rápida y un manejo adecuado. También alertamos sobre el uso de la carbamazepina, que debe siempre ser inspeccionado, especialmente en los ancianos. 